\title{
Human Rights of Migrants: From Desert Migration to Resettlement
}

\section{Nnawulezi Uche*}

Faculty of Law, Alex Ekwueme Federal University, Ndufu-Alike, Ikwo, Ebonyi State, Nigeria.

\section{Adeuti Bosede Remilekun ${ }^{* \star}$}

Department of Legal Drafting and Law Review, Attorney General's Chambers Ministry of Justice, Alagbaka, Akure, Ondo State, Nigeria.

\begin{abstract}
The issue of desert migration has remained an intractable problem in the context of human rights. Desert migration raises unabated and a major concern because of the problems that come with it. Illegal migration has highlighted the need for and the challenge of having a proper human rights impact assessment of desert migration which will help in providing a suitable legal framework. This article primarily seeks certain protections accorded to migrants on desert migration and identifies problems associated with desert migration and the states of stranded migrants under human rights law. It is written by using a doctrinal legal research methodology that adopts analytical and qualitative approaches and builds its argument on existing literature which is achieved by synthesis of ideas. This article noted that there is a significant protection gap in the international and regional human rights architecture which oftentimes result in inadequate protection of migrants from human rights violation. It is argued that in order to guarantee a robust protection of migrant's rights outside their place of origin, a more integral response to critical human rights and development challenges is capable of addressing the protection gap. Furthermore, the article demonstrated that adopting a new approach with comprehensive instruments on migrant's rights protection and resettlement will be able to eradicate unabated violations of migrant's rights around the globe.
\end{abstract}

Keywords: Desert migration; Migrants; Legal protection; Resettlement; Human rights law.

\section{INTRODUCTION}

Over the years, migration is arguably been a social phenomenon that is the natural result of human nature. Migrants all over the world have recognizable rights which are protected by law. The tragic fact of discrimination in migrants' place of residence, which violates domestic and international legal instruments, reflects an inadequate protective tool as well as protection gap of those instruments. However, arbitrariness and migrant's rights violation continually raises the questions of how just and equitable the migration laws are. Continuation of this warped sense of justice is perpetuating injustice against migrants and encourages discriminatory practices.

Desert migration is a specific topic on migrations that represents various forms of human rights violations. Desert migration exposes challenges ranging from poverty, discrimination, lack of access to education,

\footnotetext{
*Email: uchennawulezi@gmail.com and nnawulezi.uche@funai.edu.ng

${ }^{* *}$ Email/Corresponding Author: bose de lizabe th@gmail.com
} 
lack of health care facilities, and negative effects of climate change along with environmental degradation. In the light of the above, the primary purpose of this article is to investigate certain protections accorded to migrants on desert migration. Besides, it aims to identify problems related to desert migration and the states where migrants are stranded migrants, analyzed from human rights law perspective. Through a doctrinal legal research methodology and qualitative approach, this article builds its argument on existing literature which is achieved by a synthesis of ideas.

The analytical part of this paper is begun with a clarification on the definition, concept, and rights of desert migrants along with challenges arising from it. Next, it reveals the causes of migration and scrutinizes the categorization of an internally displaced person. In addition, it discusses the notion of resettlement in relation to the non-refoulement principle. Further, the paper identifies the means of the international protection system as provided by relevant legal instruments. Finally, it summarizes all findings, basic ideas, and opinions in the conclusion as well as proposing some constructive recommendations.

\section{RESULT AND ANALYSIS}

\subsection{Desert Migrant: Definition and Concept}

\subsubsection{Definition of Migrant}

In a common understanding, migrant represents those who travel from his place of birth to another country of interest either for a permanent or temporary stay which may be for several reasons or desires. The concept "migrant" has no generally accepted definition, but more importantly, International Organization for Migration (IOM) perceives it as persons, and family members, who moving to another country or region to better their material or social conditions and improve the prospect for themselves or their family. ${ }^{1}$

Several humanitarian agencies define migrant as any person or individual who is domiciled outside his place of origin or stateless outside his place domicile ${ }^{2}$ to seek protection or opportunities for a better livelihood. ${ }^{3}$ Moreso, taking into account various conceptions on migrants, "a migrant worker" in the context of this paper is any person that is engaged or has been engaged in a paid job outside his place of origin or not an indigene

\footnotetext{
1 See International Organization for Migration, "Glossary on Migration", in $\begin{array}{lllll}\text { International Migration Law, } & \text { Vol.25 61-62. }\end{array}$ https:// publications.iom.int/system/files/pdf/im125_1.pdf

2 OHCHR, "Recommended Principles and Guidelines on Human Rights at International Borders" Geneva, (2014), 11-56. Available online at https://www.ohchr.org/Documents/Issues/Migration/OHCHR_Recommended_Principles_ Guide lines.pdf; accessed on the $4^{\text {th }}$ Januaary, 2021

3 International Federation of Red Cross and Red Crescent Societies, "Policy on Migration" (2009), 2-10. https://www.ifrc.org/Global/Governance/Policies/migrationpolicy-en.pdf
} 
of that country of residence. ${ }^{4}$ In this sense, the above situation also applies to all migrant workers and members of their families in that country of residence without any form of discrimination arising from sex, race, colour, language, religion or conviction, ethnic or social origin, nationality, marital status, birth or another status. ${ }^{5}$ This perspective, however, takes into account other groups of persons who may be viewed as persons who do not have any place of origin as well as refugees when special protection is to be accorded to them.

\subsubsection{Human Rights of Migrant}

Generally speaking, "migrant's rights" as a concept does not have a universally accepted definition, but its history is dependent on the views propounded by different human rights practitioners. It must be emphasized that the major objective of the International Convention on the Protection of the Rights of All Migrant Workers and Members of Their Familie s (ICMW) is to foster respect for migrant's rights. Also, it should be noted that the Convention does not create news for migrants, but aims at guaranteeing equality of treatment with that of the nationals.

In addition, a conceptual question of importance is whether human rights law can be applied at all times, thus, in armed conflict as well, given that the philosophical basis of human rights is that it must be protected at all times. ${ }^{6}$ In times of war, human rights treaties are suspended in which states parties tend to derogate from the provisions of human rights with an exception to "hardcore rights". Recent developments in human rights practices have shown that there is a compelling reason to apply certain guarantees in ensuring the maximum protection of the "hard-core" rights. ${ }^{7}$ However, it must be emphasized that there is a great challenge in the application of human rights law as provided in the treaties which is solely dependent on the type of language used in drafting the treaty. In this sense, there is a clear difference between its interpretation in practice and actual implementation which takes into consideration other people's rights. ${ }^{8}$ In the context of International Humanitarian Law, protected persons shall be

${ }^{4}$ International Convention on the Protection of the Rights of All Migrant Workers and Members of their Families, (2009), Art.1.

5 Ibid.

6 See Jinks Derek, "International Human Rights Law in Times of Armed Conflicts," in The Oxford Handbook On International Law in Armed Conflict. ed. Andrew Clapham and Paola Gaeta (Oxford: Oxford University Press, 2014), 656; See also the extension interpretation to the Universal Declaration of Human Rights (1948) Art. 6 and International Covenant on Civil and Political Rights (1966), Art. 16.

7 See American Convention on Human Rights (1969), Arts. 7(6), 25(1) and 27(2). See also Advisory Opini on OC-9/87, Judicial Guarantees in State of Emergency, Inter- American Court of Human Rights, 6 October 1987, paras. 36-40. See also United nations Human Rights Committee, General Comment No. 6: Article 5 (Right to Life), 30 April 1982, para 1 and 2.

8 See Rosalyn Higgins, "Derogations under Human Rights Treaties", British Yearbook of International Law 48, No.1(1976):281. 
treated under humanity without any discrimination of religion, race, political opinion, or even nationality. ${ }^{9}$

\subsubsection{The Concept of Migration}

Due to several issues bordering on migrant's rights protection outside their place of origin remained an intractable problem, different approaches on having a specific definition of the concept have emerged. Thus, in literal terms, the concept" migration" is perceived as a movement of individuals from their place of origin to their place of residence either for a temporary or permanent settlement. ${ }^{10}$

Furthermore, the concept "migration" is perceived as "the act or an instance of moving from one country or region to settle in another". ${ }^{11}$ It should be pointed out that as much as "migration" has various meanings, its understanding and perception shall continue to change as time goes by. Recently, various definitions and understanding of the concept have evolved and become more complicated in approach. Similarly, treaties on international migration defined international migrants as an individual or group of individuals who migrates from their country of origin to their country of residence for a certain period of time which may be one year or more as the case may be. ${ }^{12}$ Apart from this fundamental definition developed for measurement purposes, the improvement in the concept and definition of migrant would allow further classification of migrants or characterization of the complexity of migration.

The 2030 Agenda addresses the issue of international migration by including explicitly some migration-related targets as provided in the Agenda of the Sustainable Development Goals programmes (SDGs). ${ }^{13}$ The SDGs encourage most countries to "facilitate orderly, safe, regular and responsible migration and mobility and to implement well-managed migration policies", considering international migration from the perspectives of migration. While the terms "orderly", "safe", "regular" and "responsible" are frequently used in everyday life, thus, characterization of these types of population mobility often entails ambiguity, leaving much room for subjective interpretation. In view of the concept of migration, this paper shall dwell

9 Geneva Convention Relative to the Protection of Civilian Persons in time of War of 12 August 1949(GCIV), Arts. 27, 44 and 70 and the deep analysis on this issue in Helen Obrego" $n$ Gieseken, "The protection of migrants under international humanitarian law," International Review of the Red Cross 99, no.1 (2017): 121-152.

10 See International Organization For Migration, "World Migration Report 2020", Ge neva, 2019, 1-125.

${ }_{11}$ Pieter Kok, "The Definition of Migration and it's Application: Making Sense of Recent South African Census and Survey Data", South African Journal of Demography7, no.1(1999):19-30.

12 See United Nations Demographic and Social Statistics Population Division, New York 2017. Available on line at https://unstats.un.org/unsd/demographic-social/census/ accessed 21 July 2021

13 See Nnawulezi Uche and Adeuti Bosede, Expanding the Frontiers of the Right to Work through Migration: An Evolving Regime, Brawijaya Law Journal 8, No.1 (2021): 7-8. 
more on desert migrants who may be entitled to one form of protection or the other.

The term' desert migration' is often used in various types of publications, without any further explanation. ${ }^{14}$ It also merged as phrases, for example, 'desert migration route', ${ }^{15}$ or 'desert migration management as a project activity of the IOM. ${ }^{16}$

The concept of "desert migration" has not been expressly defined in any treaties, declarations, and/ or in any human rights laws. In that regard, its ambiguity has made it difficult to arrive at a common definition. Thus, this concept is otherwise perceived as a movement of migrants from their place of birth to their country of interest in search of a better source of livelihood. It is submitted that the term "temporariness" as associated with desert migration has remained an intractable problem when it comes to the definition of the concept. thus, the question now in the circumstance is, what determines the length of time? It is clear from the foregoing that every attempt made in arriving at a uniform understanding of the desert migration concept of course has remained futile.

The Office of the United Nations High Commission on Human Rights (UNHCR) in a proper perspective defines an international migrant as any individual or individuals who moved from his or their place of birth of which he or she is a citizen or national of other countries to another place of residence in search of greener pastures which is different from a stateless person. ${ }^{17}$ Besides, it is important to realize that the categories of persons defined as migrant workers are provided under the ICMW. ${ }^{18}$

Also, it seems to be generally accepted that applying the term "migrant" in the definition of the subject under review is of course not to undermine the status of the refugees, stateless persons, or similar persons under this condition, but rather to adopt a general term that is allembracing that represents all these categories of individuals.

Despite the importance and all-encompassing language construction of the Universal Declaration of Human Rights (UDHR) provisions, desert migrants have various reasons for living their country of origin to their

14 See Regina Römhild, et.al, "The border as research space: Potentials of historical and contemporary border narratives for a better understanding and addressing of migration," in Yearbook Migration and Society 2020/2021, ed.Hans Karl Peterlini and Jasmin Donlic (Wetzlar: Majuskel Medienproduktion GmbH, 2021), 19; See also Inka Stock, "Transit to nowhere: how Sub Saharan African migrants in Morocco confront life in forced immobility" (PhD thesis, University of Nottingham, 2013), 105

15 See European Commission, "The European Union Emergency Trust Fund For Stability and Addressing The Root Causes of Irregular Migration And Displaced Persons In Africa," Action Document for the implementation of the North Africa Window T05 - EUTFNOA-LY-06, 12 November 2020, 1-12.

16 See International Organization for Migration, "IOM Libya Needs and Activities Three Year Plan 2019 - 2021"January 2019, 5-8 and International Organization for Migration, OM, EU Train Libyan Mediterranean Migrant Rescuers, 1 June 2017 https:// www.iom.int/news/iom-eu-train-libyan-mediterranean-migrant-rescuers

17 See OHCHR, Recommended Principles and Guidelines on Human Rights at International Borders, 2014 Chap 1, para 10.

18 Ibid., Art. 3(d). 
country of destination despite their vulnerability to all forms of human rights violation. Desert migration is associated with all forms of risks ranging from sexual violence and other human rights violations as noted under International Migration Law.

The se control measures through stringent legislation that criminalizes irregular migration and/ or placement of specific bans that restrict the movement of migrants to their place of interest have manifested in several forms either by enacting stringent immigration laws with difficult visa application requirements which will discourage a prospective migrant, instead, he will resort illegal migration as a short cut to actualize his dream of searching for greener pastures outside his country of origin. ${ }^{19}$

\subsubsection{Notable Challenges Arising from Desert Migration}

The nature of the challenges faced by migrants in desert migration stems from persecution to all forms of human rights violations. The challenges ranging from poverty, discrimination, lack of access to basic rights such as education, lack of health care facilities, negative effects of climate change as well as environmental degradation are all associated with desert migration.

Under the framework of the right to life, no matter the reason behind such migration, states, and their agencies should at all times provide adequate measures capable of protecting the human rights of these migrants who are vulnerable to any form of violation whether stranded and/or on transit. ${ }^{20}$ Since the position of a stranded migrant or migrant on transit is not adequately provided either in the regional or international instruments.

One practical measure to address these challenges is to look out for more comprehensive legal frameworks capable of protecting the rights of irregular migrants which should be integrated into the existing ICMW. Besides, it should be also in line with International Labour Organization (ILO) Conventions on Migrant Workers that confers the right to stay and to take up legal employment. ${ }^{21}$

Several challenges faced by migrants who are vulnerable to human trafficking and all forms of sexual exploitations have remained an object of debate amongst human rights scholars and practitioners. The se concerns emerge of state obligations in ensuring adequate protection of the rights of all migrants at all times, for example, on the access to health care facilities.

International protection of all migrants is of great value as equality that should characterize the world we live in, and as such, the IOM has played an important role in connection with having the largest set of survey

${ }_{19}$ Maybritt Jill Alpes and Ninna Nyberg Sorensen, "Migration Risk Campaigns are Based on Wrong Assumptions", Policy Brief, Danish Institute for International Studies, May 2015, 16.

${ }^{20}$ See Universal Declaration of Human Rights (1948), Art.3; International Covenant on Civil and Political Rights (1966), Art. 6(1).

21 See ILO Convention No. 97 (1949), Art. 9(1). 
data on various cases of human rights abuse against migrants bordering on exploitation and human trafficking along the Mediterranean routes to Europe and other parts of the world. ${ }^{22}$ The paper noted on the basis of the available data that over 16,000 migrants interviewed who are from Syria, Afghanistan, Pakistan, Nigeria, Iraq, and Eritrea provided a clear picture of where and to what extent migrants are vulnerable to all forms of risk of exploitation during their migration.

In a similar vein, the problem of migrants is not a new phenomenon in countries like Libya where migrants have to stay for a long period of time in order to cross the sea before reaching their country of interest. Libya is known as a country where migrants are less protected while on transit and oftentimes has led to an increase of lawlessness and abuse of their human rights. Migrants who found themselves in countries like Libya, as well as Somalia and South Sudan, while on transit are regarded as an endangered species for the most dangerous route they passed. ${ }^{23}$

\subsection{Rights of Migrants}

A key point to note on the rights of migrants at home is that there are several legislations and treaties in place that protect and promotes the rights of migrants at home. At the regional levels, the African Charter on Human and Peoples Rights guarantees the right to a general satisfactory environment favourable to the development of all peoples, including migrants. ${ }^{24}$ Similarly, the above overview highlights that aside from existing law that provides protection for migrants, a significant institutional advancement that is complementary with the existing human rights instruments also provides different forms of human rights protection for migrant individuals which could be direct or indirect protection at home. Most significant among the se human rights instruments are the UDHR, the International Covenant on Civil and Political Rights (ICCPR), the International Covenant on Economic, Social and Cultural Rights (ICESCR) 1966, and the other international convention dealing with specific social groups such as ICMW, the Convention on the Rights of the Child (CRC) 1989, the Convention on the Elimination of All Forms of Discrimination against Women (CEDAW) 1980, the United Nations Declaration on the Rights of Indigenous People's 1969, the Convention Relating to Stateless Persons 1954 as well as the Convention on the Reduction of Statelessness 1991 respectively.

22 Eliza Galos, Harry Cook, and Laura Bartolini, "Migrants Vulnerability to Human Trafficking and Exploitation in the Irregular Migration Context of the Mediterranean Routes", Migration Policy Practice VII, No. 2(2017): 5.

${ }^{23}$ See European Commission, loc.cit." See also North Africa Mixed Migration Hub, Survey Snapshot: Italy, December, (2016) and Office of the United Nations High Commissioner for Human Rights and United Nations Support Mission in Libya. Detained and Humanized: Report on Human Rights Abuses Against Migrants In Libya (2016), 1-32. Available online

https:// www.ohchr.org/Documents/Countries/LY/DetainedAndDehumanised_en.pdf; accessed on the 14 January, 2021

${ }^{24}$ African Charter on Human and Peoples Rights, Art. 24. 
The above conventions and documents provide a general application to migrant's rights protection outside their place of origin whether internally displaced or not. Migrants at home also benefit from this human rights protection which ranges from freedom of movement, unwarranted expulsion, and violence and intimidation as well as other forms of rights.

At the regional levels, similar concerns have already been expressed on the scope of migrant's rights by the Economic Community of West African States (ECOWAS)' protocol that deals with the issue of freedom of movement of persons from their place of origin to their place of interest. The protocol enables ECOWAS countries' citizens to enter, reside and establish a territory of an ECOWAS member without any molestation or abuse. ${ }^{25}$ The essence of the above is to guarantee maximum protection of their citizens who are outside their place of origin as well as establishing common ties amongst the countries in the Africa region.

\subsubsection{Causes Of Migration}

It is pertinent to point out that there are many factors responsible for migration. It is settled that migrants moved from their place of origin to their place of interest for either economic reasons, disaster, or as a result of Internal crisis in their country of origin. In a similar vein, migrants may have faced several challenges that will compel him or them to leave his or her country of origin to seek greener pastures outside their country of origin.

Another scenario that illustrates the reasons for migration maybe as a result of political circumstances which may lead to people fleeing either as a result of war, insurgency, militancy, and/or banditry that may give rise to all manner of human rights violations or similar circumstances that has created insecurity and climate of fear. Specifically, In this context of human rights abuses, cases of refugees are often found in neighbouring countries as asylum-seekers.

Similarly, migration could be a result of an environmental or sudden change in the atmospheric condition of that country which may compel forced or voluntary migration of individuals to another country for safety. Also, instances of natural disasters can compelling people to move out of their country of origin for safety. In addition, it should be noted that instances of political instability in a country can compelling one to migrates from his country of origin to another. In the light of the above, it is evident that all migrants are faced with one situation or the other given the prevailing circumstance as they continue to live and work in their place of residence, they are faced with several challenges ranging from adapting to a country's socio-cultural lifestyle different from theirs. Furthermore, as strangers, they are being denied basic rights, as well as denial of protection of their human rights at all times with the notion that they are strangers and not entitled to any form of human rights protection from their country of residence. It is noteworthy that the above situation, however, contributes

25 See Economic Community of West African States, Protocol Relating to Free Movement of Persons, Residence, and Establishment, 1979, Art. 2(1). 
to migrants' difficult access to social protection and welfare in their country of residence.

\subsubsection{Internally Displaced Persons: Are They Migrants?}

One of the most outstanding and positive developments under Migration Law was a proper interpretation of the concept of Internally Displaced Persons (IDP). Therefore, it is our considered view that the notion of internally displaced persons is now widely adopted by humanitarian practitioners as well as policymakers, while the concept has remained problematic. Without prejudice to the foregoing, there has never been a universal definition of the above concept at the international level of operations. Several efforts have been made to arrive at a uniform definition of the concept, to bridge various dimensions of the concept that may cover a broad or even a narrow scope of definitions. ${ }^{26}$

The concept of IDP has various interpretations depending on how and who is defining it. It may be seen as persons who as a result of continuous harassment, hostilities, or brutality; unwillingly flew from their known abode but still decide to remain within the jurisdiction of the country. ${ }^{27}$

Similarly, the IDP in a broader term may also be defined as individual or group of individuals that are mandatorily coerced to abandon to leave their known native land of abode due to unending catastrophe or flee from the hostility bestowed on them by calamity caused by armed humans or bandit who has never crossed an international state border. ${ }^{28}$

The complexity of the above definitions gave rise to several issues that require further clarifications. In a situation of violence and persecution that prompted human migration outside the territorial borders of a country, it is regarded as migrants on transit or stranded migrants, while those who remained in their country of origin are being regarded as IDP.

Those who flee outside their country of birth for safety may enjoy better protection than those who remained in their country of origin. This position is justified by the former United Nations Secretary-General who submitted that "It is inadmissible that those who have managed to cross the border should benefit from the rules of international law while, at times only several hundred meters away, those who were not able to leave their country remain unprotected. ${ }^{29}$

It can thus be said individuals who left their country of origin caused by civil war or internal armed conflicts have not sought refuge in other nations, may be regarded as IDP. This type of person is entitled to adequate

26 See Analytical Report of the Secretary-General on the Definition of Internally Displaced Persons(1992), 23.

27 UNHCR, "The State of the World's Refugees: A Humanitarian Agenda" (Oxford : Oxford University Press, New York, 1997), 99.

28 See United Nations High Commissioner for Refugees, Guiding Principles on International Displacement, 22 July 1998, Introduction: Scope and Purpose, para 2.

29 Boutros Boutros-Ghali, "In Rome, Secretary-General Speaks In Support Of Displaced Persons," United Nations Press Release SG/SM/5866 January, 1996. 
protection like that giving to refugees since they have not crossed international borders as to be covered by relevant laws on refugees.

Nonetheless, for an apt consideration and appreciation of the above concepts, it is pertinent to emphasize that State Parties are under an obligation to protect, respect, and ensure the rights of IDP are adequately protected at all times. Those who are internally displaced are most times not adequately protected and/or giving necessary assistance even when their situation is a legitimate concern of the State.

That being said, the entire provisions of the Guiding Principles on Internal Displacement 1998 will be a veritable tool for sustainability, sufficient instruction, and control on internally displaced matters especially for vulnerable individuals; it is then very essential to note that the international Human Rights Laws, Refugee Laws and Humanitarian Law principles have set out standards of treatment for IDP. Thus, these have given rise to a special deliberation on the human rights of IDP that will create more awareness on its status and rights. It has been observed that the entire provisions of the Guiding Principles on Internal Displacement 1998 refer to two situations: "return" and "resettlement". In this sense, it should be noted that while some countries construed the latter to mean settlement outside one's country of origin, others saw it as a settlement in one's place of birth.

\subsection{The Notion of Resettlement: The Way Forward}

Having looked at the various conceptions on the term "migration" and rights of migrants either on transit or stranded vis-à-vis the general notion on the status of IDP in the light of the provisions of International Human Rights Law, it is obvious that human rights are those liberties, immunities, and benefits which, by accepted contemporary values, should be enjoyed by all human beings as of right. ${ }^{30}$ It is a right tied to humanity that even in the absence of enforcing machinery does not deny its existence status.

Under the resettlement assistance, the International Organization for Migration has played a key role in global resettlement. In this regard, resettlement could be viewed as an instrument mapped out to meet the necessities of refugees and probably solutions to their predicaments. ${ }^{31}$ There is a need to advocate legal frameworks that are capable of driving and shaping the resettlement agenda which will be in line with the principles of Human Rights Laws and Refugee Laws.

The basic purpose of resettlement is to serve as a protective tool that will ensure adequate provisions of shelter for displaced persons or migrants who are outside their place of birth as a result of one reason or the other. It could be seen as an instrument of responsibility sharing and as a durable solution in specific circumstances. The policies and the criteria to be applied in such situations should be done in a consistent manner as well as being

30 See Universal Declaration of Human Rights, 1948, Arts. 3 and 13.

31 See International Organization for Migration Office in Belarus, "Movement," https://iom.by/en/activities/movements 
transparent and should strive to avoid lopsidedness. In situations of resettlement, there exist too many variables ranging from political will, place of origin, and issues bordering on quota. Thus, recognizing the level of awareness on resettlement at international, regional, and national levels, it must be emphasized that the UNHCR has further broadened its position on this important protective tool which has made resettlement become part of its operations, that still fall into its competence and function. ${ }^{32}$

The word "resettlement" means the selection and movement of known refugees to an entirely new environment or abode outside their native land in order to seek protection from a third party state who had earlier concur to render maximum protection for them without any form of requirement. Thus, this form of resettlement status provided to them guarantees their protection against unlawful repatriation and ensures that these refugees or migrants and their family members or dependants have access to the basic rights similar to those enjoyed by the nationals of that country. The issue of non-refoulement principle 33 is fundamentally important in the context of resettlement because African refugees syndrome has of late, come to be worrisome. Not just because of the massive nature of this problem, but also because some of the migrants who are refugees properly so-called are sometimes repelled at the frontiers by some African countries. Migrants seem to be profiling as aliens and that the reception of aliens is an exclusive and discretionary right of every sovereign state, and that except through special treaties, ${ }^{34}$ no state can claim for its citizens, the right of entry into another state for residency purposes. ${ }^{35}$

It is against the background of the state's omnipotent capacity to admit or exclude non-nationals or aliens from its territory that in the light of the precarious circumstances of the migrants as discussed earlier in this paper, that they have been shielded by the non-refoulement principle. In this regard, provides that contracting party to the convention shall not expel or hand-over a refugee back in a manner where his life or freedom might be in jeopardy or danger due to his origin while in his host country.

In that respect, the philosophical basis of the main import of the nonrefoulement principle which is anchored on adequate security, safety, and protection of migrants suggests that the human rights of migrants or refugees should be adequately protected at all times whether in their place of origin or not. In this sense, the paper noted as follows: First, that resettlement is an instrument that provides international protection for the individual whose fundamental human rights are threatening or in danger. Second, such protection must be long-lasting for all refugees and their repatriation and local integration process. Third, such protection rendered

${ }^{32}$ Statute of the Office of the United Nations High Commissioner for Refugees (1950), Art. 6.

33 This principle is stipulated in Convention Relating to the Status of Refugees, 1951, Art. 33 (1). 336-337.

${ }^{34}$ J.G. Starke, Introduction to International Law (London :Buttersworths, 1984), 234-357.

${ }^{35}$ L. Oppenheim, International Law: A Treaties(, London: Longmans, Green, 1952), 
to refugees is an expression of international solidarity that allows states to assists refugees by providing adequate protection, and as well reduce their burdens.

International protection and identification of durable solutions are viewed as the UNHCR's core objectives, however, its mandate has been expanded in recent times through the resolutions of the United Nations General Assembly regarding on resettlement. Ultimately, the above two concepts have played a significant role in achieving the objectives of the UNHCR. Resettlement has remained an invaluable protective tool used in addressing all the essential needs of all refugees problems outside their place of origin. In this context, it becomes all the more relevant to emphasize that the se voluntary repatriation, local integration, and resentment are very germane and are important solutions to address refugee problems. In this case, It must be stated that the main purpose attached to resettlement policy is providing a long-lasting solution for refugees who are willing to go back to their native land or retain their refugee status; this is because of the long-lasting protection that ought to be given to refugees are lacking.

It must be emphasized that every refugee deserves ultimate protection from his country of residence or refuge. Relying on the aforesaid, that the concept of resettlement has been expanded following the adoption of the convention plus Initiative in 2004 as well as the Agenda for Protection in 2002. The Agendas for the protection of refugees have its primary objective in expanding resettlement opportunities that will enhance a broad range of resettlement issues in several countries of the world by applying more strategic use of resettlement techniques that will benefit many refugees by the introduction of capacity building programmes for various countries which encourages countries to increase their quotas through different means of accepting refugees ${ }^{36}$ that will be resettlement friendly. In the same vein, it must be acknowledged that resettlement has remained a vital means of showing international solidarity in addressing refugee's resettlement problems. However, attention needs to be paid to the strategic approach to solving problems of assessment and identification of those who genuinely need resettlements in order to maximize the protection benefits.

\subsection{Overview of International Protection System}

The status of refugees is embedded in the 1951 Convention Relating to the Status of Refugees (hereinafter the 1951 Convention) and the 1967 Protocol relating to the Status of Refugees (hereinafter the 1967 Protocol), and other regional treaties and declarations placed on the rights of refugees. Notwithstanding the above possibilities, it is a fact that the question of whether obligations to provide long-term rehabilitative care lies on the regulatory system of international human rights law depends on the scope of application of international human rights law during armed conflict. Furthermore, it must be emphasized that the UNHCR is responsible for the

${ }^{36}$ There has been a series of a high-level dialogue that aims to link the migration and development. See for example, Philip Martin, Susan Martin, and Sarah Cross, "Highlevel Dialogue on Migration and Development," International Migration, 45, No. 1 (2007):7. 
provisions of international protection to all Refugee Migrants as well as providing solutions to refugee's problems around the globe. Also, a discourse on providing an international legal framework capable of providing adequate protection for internally displaced persons within or outside the region of Africa is needed is of course, necessary and should be in line with the desired standards of treatment that governments and/or its agents should be encouraged to observe. ${ }^{37}$ As a priority issue, the protection of Migrant refugees has remained an important part of the UNHCR priority issue. In this regard, it has been observed that in order for a country to protect refugees, such country must secure their presence and proper admission into her country and ensuring that their rights are protected and respected until they are properly settled or a durable solution is found. Also, in the context of international protection of refugees, a durable solution is an element of responsibility-sharing with the country of asylum. Therefore, the United Nations human rights mechanisms are capable of being used to enhance migrants' protection. Suffice to point out however that the United Nations human rights machinery is complex:- the mandates, competence, and experience of different United Nations bodies dealing with human rights vary enormously.

In the light of the above, the issue of international protection, in other words, pertains to the international legal order of the United Nations enforcement mechanism applied in such a manner that migrant refugees' rights are adequately protected outside their country of origin. Similarly, it may be understood to mean actions exhibited to ensure unrestricted equal access and enjoyment of human beings who may be migrant refugees or protection giving to migrant refugees outside their place of birth in accordance with the provisions of the law.

\subsubsection{Some Notable Legal Instruments}

In this connection, it is interesting to examine some of the notable legal instruments that guarantee legal protection to migrant refugees. In all contexts, the 1951 Convention and the 1967 Protocol protect the rights of refugees within their host countries and their native land. The next description will explain some relevant legal instruments that also guarantee their rights.

\section{a. The 1951 Convention Relating to the Status of Refugees and the 1967 Protocol relating to the Status of Refugees}

In furtherance to the enhancement of the recognition of the status of refugees and their deserved recognition around the globe, the 1951 Convention represents the legal instrument that is responsible for such protection and recognition under International Refugee Law. It outlined what qualifies one as a refugee and the deserved Standards for their treatment outside their place of origin and/or while in asylum condition

37 Roberta Cohen, "Protecting the Internally Displaced", World Refugee Survey 1996, U.S. Committee for Refugees, Washington, D.C., 1997, 3. 
The entire provisions of the 1951 Convention provided a platform for a universal definition of a refugee amongst State parties to the Convention, defining refugee either on the basis of the ethnic, national group, or State of origin. Aside from the UNHCR Statute, the 1951 Convention initially provided a clear picture of persons who became refugees as a result of events occurring on or before 1 January 1951.

\section{b. International Convention on the Protection of the Rights of All Migrants Workers and Member of their Families}

It should be noted that the ICRMW is majorly categorized as one of the seven human rights instruments that are very fundamental to defining basic and universal human rights. Others are the ICCPR, ICESCR, Convention Against Torture (CAT), CEDAW, and CRC.

However, it is maintained here that the relevance of the 1990 Convention stems from the fact that migrant workers are construed as having a better status than laborers or economic entities. The above convention was made to prevent and eliminate illegal migrants within the country and provide last-longing protection for migrant workers and members of their family and also provide means of recognition and bringing closer legislation to stand side by side with international standards

\section{c. The 1969 Organization of African Unity Convention Governing Specific Aspects of Refugee Problems in Africa}

The 1969 Organization of African Unity Convention Governing Specific Aspects of Refugee Problems in Africa applies not only to persons fleeing from persecution but also to those fleeing from situations of external aggression, occupation, foreign domination, or events seriously disturbing public order. ${ }^{38}$ In most African Countries, the status of refugees instances of refugees fleeing from their country of origin to another as a result of one problem or another is a commonplace issue. It is vital to note that the promulgation of the 1969 African Union Convention is now universally implemented and not limited to the African region alone.

\section{d. Cartagena Declaration on Refugees $1984^{39}$}

The Cartagena Declaration possessed a unique characteristic in that recommended in their entire ty the status of a refugee; that any refugee who left his native land of threat to their fundamental human right as a result of an attack or other means of violence that have disturbed the society. This type of declaration has provided the basis for easy identification and/ or recognition of refugee status in some of the Latin American countries in recent years. ${ }^{40}$

38 Organization of African Unity Convention Governing the Specific Aspects of Refugee Problem in Africa, 1969, Art. I (1) and (2).

39 See Cartagena Declaration on Refugees, Colloquium on the International Protection of refugees in Central America, Mexico and Panama, 1984, Art.1.

40 See the Bangkok Principles on the Status and Treatment of Refugees adopted by the Asian-African Legal Consultative Organization in 2001, Arts. 1(a)(b), 2 \& 3. 


\subsubsection{Shortcomings of the Existing Legal Instruments}

It is evident from the foregoing that some of the above notable instruments have some shortcomings which have either made its implementation difficult or acce ptable globally It is based on the above that this paper made the under-listed observations.

First, there is a weak implementation standard and or delay in the adoption of the existing treaties. The paper noted that among the total number of sovereign states in the world, there are not so many countries that have ratified or acceded to the ICMW and this remained a worrisome situation. At another extreme, it may seem clear that the said delay in the ratification of the ICMW may be as a result of disinterestedness in that legal instrument which symbolizes general resistance to the recognition of the application of human rights standards to migrants, especially the undocumented migrants whose existence in their country of refuge is not on record or could be found anywhere. Second, the designation of some persons in the statute as "illegal" has informed the denial of their le gal protection as well as their basic rights in the country where they are seeking asylum. Third, the existing legal framework does not provide for nongovernmental organizations and migrants access or opportunity in contributing or participating in international policy formulations. Forth, the existing instrument provides what we may term "dichotomization of human rights" for which International Law has recognized victims of violations of political rights as a migrant refugee that needs protection and assistance. Lastly, the level of attention given to migration control does not reflect in the protection of their human rights which has a militating factor under International Migration Law.

\section{CONCLUSION}

This paper has largely dealt with migrant's rights from a human rights perspective. From the discussions so far, we have been able to establish that migrant's rights abuses are endemic all over the world. The vulnerability to these abuses and exploitation is greatly compounded and exacerbated by other conditions such as belonging to a minority group. Many treaties or protocols have considered migrants as vulnerable persons who deserves adequate protection and resettlement

A further observation made in this regard is that the existing legal instruments are weak and not capable of protecting the human rights of migrants, and in particular, providing adequate resettlement mechanisms for desert migrants or those on transit.

This study is not to be seen as an end but rather as a beginning of a new process aimed at improving an understanding of an agreement on the principles or role of international human rights law on the status of migrants who deserve adequate protection and resettlement outside their place of origin. Thus, this principle embedded in some conventions and protocols respectively rested at the core of refugee protection and are considered to have a basis outside the conventional laws. As an example, the 1951 Convention regulated not only the personal status of refugees as a 
special category of persons but also provided a certain level of human rights protection, such as non-discrimination and freedom of movement that were subsequently developed in regional and international legal frameworks.

The issue of human rights of migrants has created several legal problems that must be settled once and for all. Accordingly, it is recommended that several actions can help in addressing some of the intractable problems. Thus, the following recommendations may be of help if well adopted or implemented. First, there is a compelling need for mutual cooperation between the UNHCR and State Parties in the area of facilitating the identification of undocumented migrants as well as providing adequate resettlement facilities for them. Second, there should be regular updates on information bordering on desert migrant's problems both at the regional and international levels of operations. Third, in addressing protection problems faced by desert migrants, it requires the gathering of information about such migrant outside his country of residence and or other countries where he has links which may be either his place of birth, descent, or his former place of residence. Forth, the host State should provide an adequate and sustainable resettlement framework that will provide access to empowerment and livelihoods. Fifth, desert migrants should be provided with a long- term safety, security and freedom of movement since such efforts at assisting and protecting them is in line with international standard. Sixth, the resettlement policy of the host country should be a long-lasting one as well as being capable of assisting such migrants who are unable to voluntarily return home or to remain in their country of refuge as the case may be. Ultimately, it is worthy of note that full adoption of the above recommendations made in this paper will further strengthen the efforts made in protecting the human rights of migrants through resettlement. It is not in doubt that the adoption of the recommendations at the domestic or international levels will certainly increase the protection and resettlement desired by all migrants.

\section{ACKNOW LEDGMENT}

This article is written based on a paper with a title Human Rights of the Migrants: From Migration to Resettlement, written by Uche Nnawulezi, in a conference with a theme "Reframing Migration and Human Rights; Border Crime and International Security in the Discourse of Globalisation", organized by Dominican University, River Forest, Illinois, the United States of America on 3-5 October 2019.41 The current version of the article has further developed the idea, opinion, and sources of the abovementioned paper.

41 The abstract is available in Conference, "Reframing Migration and Human Rights; Border Crime and International Security in the Discourse of Globalisation", organized by Dominican University, River Forest, IL, USA, 3-5 October 2019, 16-17. https:// www.conflictsandgende rights.com/images/pdf/conference-program.pdf 


\section{BIBLIOGRAPHY}

\section{Book}

Derek, Jinks. " International Human Rights Law in Times of Armed Conflicts." In The Oxford Handbook On International Law in Armed Conflict, edited by Andrew Clapham and Paola Gaeta. Oxford: Oxford University Press, 2014.

Oppenheim, L., International Law: Treaties, London: Longmans, Green \& Co, Vol. 11, 1952.

Römhild, Regina, et.al, "The border as research space: Potentials of historical and contemporary border narratives for a better understanding and addressing of migration." In Yearbook Migration and Society 2020/2021, edited by Hans Karl Peterlini and Jasmin Donlic, Wetzlar: Majuskel Medienproduktion GmbH, 2021.

Starke, J. G." Introduction to International Law", London: Buttersworths, Ninth Edition., 1984.

\section{Journal Article}

Gieseken, Helen Obregón. "The protection of migrants under international humanitarian law." International Review of the Red Cross 99, no. 904 (2017): 121-152. https://doi.org/10.1017/S1816383118000103

Galos, Eliza, Harry Cook and Laura Bartolini. " Migrant's Vulnerability to Human Trafficking and Exploitation in the Irregular Migration Context of the Mediterranean Routes". Migration Policy Practice VII, No. 2 (2017): 34-37.

Higgins, Rosalyn. "Derogations under Human Rights Treaties". British Yearbook of International Law. 48, No.1 (1976): 281-319, https:/ / doi.org/10.1093/ bybil/48,1.281

Kok, Pieter. "The Definition of Migration and it's Application: Making Sense of Recent South African Census and Survey Data," South African Journal of Demography 7 No. 1 (1999): 19-30

Martin, Philip, Susan Martin, and Sarah Cross. "High-level Dialogue on Migration and Development. International Migration 45, No. 1 (2007): 7-25. https://doi.org/10.111/i.1468-2435,2007.00394.x

Uche, Nnawulezi and Adeuti Bosede. "Expanding the Frontiers of the Right to Work through Migration: An Evolving Regime," Brawijaya Law $\begin{array}{llll}\text { Journal } & 8, & \text { No.1 } & \text { (2021): }\end{array}$ http://dx.doi.org/10.21776/ub.blj.2021.008.01.01

\section{Thesis or Dissertation}

Stock, Inka. "Transit to nowhere: how Sub Saharan African migrants in Morocco confront life in forced immobility." Ph.D. thesis, University of Nottingham, 2013

\section{Legal Documents}

African Charter on Human and Peoples Rights, 1981.

Bangkok Principles on the Status and Treatment of Refugees, Asian-African Legal Consultative Organization, 2001

Cartagena Declaration on Refugees, Colloquium on the International Protection of Refugees in Central America, Mexico and Panama, 1984. 
Convention Relating to the Status of Refugees, 1951.

Geneva Convention Relative to the Protection of Civilian Persons in Time of War, 1949.

United Nations Human Rights Committee, General Comment No. 6: Article 5 (Right to Life), 30 April 1982.

International Convention on the Protection of the Rights of All Migrant Workers and Members of their Families, 2009.

International Covenant on Civil and Political Rights, 1966.

International Labour Organization Convention No. 97 on Migration for Employment, 1949.

International Labour Organization Convention No.143 on Migrant Workers, 1975.

Organization of African Unity Convention Governing the Specific Aspects of Refugee Problem in Africa, 1969.

Protocol Relating to the Status of Refugees, 1967.

Economic Community of West African States, Protocol Relating to Free Movement of Persons, Residence, and Establishment, 1979.

United Nations Guiding Principles on International Displacement, 22 July, 1998.

Statute of the Office of the United Nations High Commissioner for Refugees, 1950.

Universal Declaration of Human Rights, 1948.

The Bangkok Principles on the Status and Treatment of Refugees adopted by the Asian- African League Consultative Organization in 2001.

\section{Other Documents}

United Nations. "Analytical Report of the Secretary-General on the Definition of Internally Displaced Persons", 1992.

Alpes, Maybritt Jill and Ninna Nyberg Sorensen. "Migration Risk Campaign are Based on Wrong Assumptions", Policy Brief, Dannish Institute for International Studies, May 2015.

Boutros-Ghali, Boutros. "In Rome, Secretary-General Speaks In Support Of Displaced Persons," United Nations Press Release SG/SM/5866 January, 1996.

Cohen, Roberta. "Protecting the Internally Displaced", World Refugee Survey, 1996, U.S. Committee for Refugees , Washington, D.C., 1997.

European Commission. The European Union Emergency Trust Fund For Stability And Addressing The Root Causes Of Irregular Migration And Displaced Persons In Africa, Action Document for the implementation of the North Africa Window T05 - EUTF-NOA-LY-06, 12 November 2020.

North Africa Mixed Migration Hub. Survey Snapshot: Italy, December 2016.

International Federation of Red Cross and Red Crescent Societies. "Policy on Migration," 2009.

International Organization for Migration. "Glossary on Migration", in International Migration Law, Vol.25, 2011.

International Organization for Migration. "IOM Libya Needs and Activities Three Year Plan 2019 - 2021. "January 2019. 
International Organization For Migration. "World Migration Report 2020", Geneva, 2019.

Office of the High Commissioner of Human Rights. "Recommended Principles and Guidelines on Human Rights at International Borders" Geneva, 2014.

Office of the United Nations High Commissioner for Human Rights, and United Nations Support Mission in Libya. Detained and Humanized: Report on Human Rights Abuses Against Migrants in Libya, 2016.

United Nations. "United Nations Demographic Yearbook 2017," Demographic and Social Statistics, Department of Economic and Social Affairs Population Division, New York, 2018.

United Nations High Commissioner for Refugees." Chairman's Summary: Inaugural Meeting of the Forum, 27 June 2003.

United Nations High Commissioner for Refugees. Guiding Principles on International Displacement, 22 July 1998.

United Nations High Commission For Refugees. Global Trends in Forced Displacement, Statistics and Demographics Section UNHCR, Copenhagen, 2019.

United Nations High Commission For Refugees. "The State of the World's Refugees: A Humanitarian Agenda" (Oxford: Oxford University Press, New York, 1997.

\section{Case Law}

Advisory Opinion OC-9/87, Judicial Guarantees in State of Emergency, Inter- American Court of Human Rights, 6 October 1987

\section{Website Content}

International Organization for Migration, OM, EU Train Libyan Mediterranean Migrant Rescuers, 1 June 2017 https://www.iom.int/news/iom-eu-train-libyan-mediterraneanmigrant-rescuers

International Organization for Migration Office in Belarus, "Movement," https://iom.by/en/activities/movements 